\title{
The Use of Gesture in Improving Students' Vocabulary Mastery in Selected Indonesian Junior High School
}

\author{
Indrayani Simpuruh \& Syamsinar Syamsinar \\ STIE Tri Dharma Nusantara, Makassar. Indonesia \\ indrayanisimpuruh@gmail.com
}

\section{ARTICLE HISTORY}

\author{
Received : 2020-12-13 \\ Revised : 2021-01-13 \\ Accepted : 2021-01-17
}

\section{KEYWORDS}

\section{Gesture}

Vocabulary mastery

Effective Technique

Students Interest

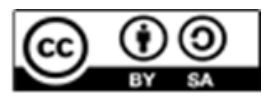

\begin{abstract}
This presents research explore on the use of-gesture to improve students' vocabulary mastery at the second grade students of Indonesian junior high school. This quantitative research involved 60 students as its sample. The pretest, treatments, and posttest were used in this study. The data obtained through test were analyzed to find its mean score and the score of t-test. The result of the study shown that there was a significant improvement of the students' achievement after giving the treatment. The data shows that the t-test obtained by the students (16.28) is greater than t-table (2.045). This is means that $\mathrm{H} 0$ is rejected and $\mathrm{H} 1$ is acceptable. The data of students' interest which were taken by using questionnaire shows that 25 students $(83.33 \%)$ are in the very high category and left only five students $(16.67 \%)$ in the high category. It means that the students were interested and this technique is suitable in teaching English vocabulary.
\end{abstract}

\section{Introduction}

Language is mean of communication that people used to convey their ideas, opinions, thoughts, and feelings to each other. English is the first foreign language in Indonesia which is important to transfer and gain knowledge, science and technology, art and culture, and establish international relationships.

For many years English in Indonesia has become a compulsory at schools (Aswad, et.al, 2019) including in junior high schools. The students need to learn language skills: reading, writing, speaking and listening. In addition, they also have learnt language components: vocabulary, pronunciation, and grammar to help them develop their language skills For example, by having vocabulary and knowing tenses, it is easy for the students to comprehend reading or to write paragraphs.

There are four language skills that students have to be acquired: listening, speaking, reading, and writing. To achieve these skills, the students have to master the language components: grammar, vocabulary, and pronunciation. In other words, these language components must go hand in hand to successfully achieve the language skills. The lack mastery of one component can affect the students' performance of the language skills. For example, if the students have limited English words or vocabularies, for instance, the students will find a serious problem when speaking English. $\mathrm{He} /$ she cannot speak fluently because they do not have a lot of words. The more words or vocabularies he or she has the easier she minds, ideas, opinions or intentions through speaking or writing.

Vocabulary is one of the language components that have an important role to support the four basics language skills. Vocabulary is very important in order to make people easier to express their opinions and ideas in their communication with other people. Having limited vocabulary, the students will find many difficulties in mastering language skills. (Pieter A, 1991) states," The fact that vocabulary is the component of language and there is no language exists without words. Words are signs or symbols for ideas. They are the means by which people exchange their language. The more words we can learn, the more ideas we should have, so we can communicate the ideas more effectively". (Harmer, 1991) states," We must have something to say, we have meaning that we wish to express and need to have stock of word that can describe how you feel at this moment, 
you have to be able to find a word which reflects the complexity of your feeling". (Birley \& Lubis, 1988) state" Effective communication is not about how many words you use, but about which words you select to use. You can only select the best words for the best occasions if you have a large vocabulary to draw from." Both states mean by having large vocabulary in the students' mind, they can choose which words they will use in their communication or in their ideas with various ways. Having more vocabularies is one of the ways to master English in producing words. We will be constraint in all aspects of language that very important to know. It has an important role in mastering listening, speaking, reading, and writing. A linguist David Wilkins in (Thornburry \& Harmer, 2002) summed up the importance of vocabulary learning in a statement that "without grammar very little can be conveyed, without vocabulary nothing can be conveyed".

There are a lot of vocabulary problems in teaching and learning process. The factor can be caused by the individualized teacher, by the method that is used, by the less of motivation and interest of the students in learning English, or perhaps the students have difficulties in mastering vocabulary. However, the students' in that level still have a little vocabulary while before, the students have learnt basic of English or just about the simple noun, etc. The teachers need good materials and well preparation to solve these problems. They should provide some new alternative ways or strategies to stimulate the students to improve their own vocabulary. The teacher should be creative in the way of teaching vocabulary to make students can build up their vocabulary and make students' interest and enjoy in class. One way to make students' interest in teaching vocabulary is by using Gesture.

In fact, students in second year at Junior High School have lack of vocabulary. They must have motivation to increase their vocabulary mastery. It is a task for the teacher of English to solve their problem. The teacher is required to have an appropriate technique of teaching. One of the technique to make students' interest in teaching vocabulary is by using Gesture.Gestures are an integral part of any communication where people listen and speak to each other.

Nevertheless, they help us get across what we want to say. For example, when we give directions in the street to a stranger, we not only use our voice to give special emphasis to the important points, we often use our hands to make things clear as well. If we are deprived of what the body can express, for example when we talk on the telephone or listen to the radio, we are forced to use our imaginations and try and extract all the meaning from the inflexions of the voice or the words themselves. With direct contact we often look at the other person's face to gauge what their real feelings or attitudes (Beattie, 2016)

Echoing the previous studies highlight the researcher used Gesture because it can be a very useful learning for the effective and enjoyful learning. Gesture can be used also as one of the interesting and enjoy learning to improve students' vocabulary achievement. Gesture helped students' associate common words and phrases with certain actions, which would accelerate their learning and give them more confidence. Furwther, hen people do some activities such as studying or other activities, they have to have a good reason to make them sure that the activities can be successful. It concludes that they are interested in that activity. Talking about interest, it refers to about the positive response or attitude to something the people like, enjoy, and appreciate which make them having a desire to do. Attempts to define interest are numerous, and a great variety of definitions have been developed, here are only a few of them. Based on the definitions explained, interest is the internal power as sources of motivation in teaching-learning process. It makes students easier to involve in the subject because they will pay attention fully on that subject in this case is English language. The definitions from many experts above show that students' interest will be shown by some aspect, they are: curiosity, attention and enjoyment (Muhammad, 2014).

\section{Method}

The method of the research was quantitative method. Before applying Gesture, the researcher gave pretest, treatment, and then posttest. The posttest gave to know the achievement of the students after doing treatment. There were two variables in this research, namely independent and dependent variable. The dependent variables were students' vocabulary achievement and students' interest. The independent variable was Gesture.

The Population of this research was second grade students of Indonesian Junior High School from two different classes (60 students). The classes were namely second grade $\mathrm{A}$ and second grade $\mathrm{B}$. This research, the researcher applied cluster sampling, to determine the sample because the object to be studied very spacious which was in second grade A consist of thirty students. The instrument consisted of two instruments, they were vocabulary test and questionnaire. In vocabulary test, there were two tests in vocabulary test, they were pre-test and posttest. Pretest was given to the students at the first meeting to measure students' vocabulary skill, the test is consisted of thirteen number in multiple choice. Post-test was given at the last meeting to measure the students' achievement after getting treatment. The test in pre-test was as same as in post-test. Questionnaire was given to get information about students' interest in vocabulary skill by using Gesture. Questionnaire was given some 
questions about students' interest in vocabulary skill by gesture.

The procedure of data collecting of the research followed the procedure as follows; pretest, treatment, posttest, questionnaire. Technique of data analysis by scoring the students' correct answer female and male, Classifying the score of the students' male and female, computing the frequency and the rate percentage of the students' scores, calculating the mean score of the students, to find out the standard deviation of the students' pre-test and post-test, to find out the significant difference between pre-test and post-test, the data from questionnaire was analysed by using Likert scale.

\section{Findings and Discussion}

The researcher has stated that the data of students' vocabulary achievement were collected by using test (pretest and posttest) and questionnaire. The tests, pretest and post-test were given to measure the students' vocabulary achievement before and after treatment. The questionnaire was given in order to know students interested on treatment by using Gesture of the second grade students of Indonesian junior high school.

\subsection{The raw, the frequency distribution and percentage of the students' score in the pre- test and posttest.}

Based on the table at the research, it can be seen clearly that in pre-test 7 student got grade very poor, 21 students got grade poor, and 2 students got grade fairly good. It means that the students' vocabulary achievement at second year students of Indonesian junior high school before giving treatment, it was will low because there was not student got good excellent grade. In post-test, it can be seen clearly that 4 students got grade fair, 10 students got grade fairly good, 12 students got grade good and 4 students got very good. It means that after giving treatment the students' vocabulary achievement at second year students of Indonesian junior high school.

Table 1. The frequency distribution and percentage of students' score on vocabulary achievement

\begin{tabular}{cccccc}
\hline \multirow{2}{*}{ No } & Classification & \multicolumn{2}{c}{ Pre-Test } & \multicolumn{2}{c}{ Post-Test } \\
\cline { 3 - 6 } & & $\mathbf{F}$ & $\mathbf{\%}$ & $\mathbf{F}$ & $\mathbf{\%}$ \\
\hline $\mathbf{1}$ & Excellent & 0 & 0 & 0 & 0 \\
\hline $\mathbf{2}$ & Very Good & 0 & 0 & 4 & 13,33 \\
\hline $\mathbf{3}$ & Good & 0 & 0 & 12 & 40 \\
\hline $\mathbf{4}$ & Fairly Good & 2 & 6,67 & 10 & 33,33 \\
\hline $\mathbf{5}$ & Fair & 0 & 0 & 4 & 13,33 \\
\hline $\mathbf{6}$ & Poor & 21 & 70,00 & 0 & 0 \\
\hline $\mathbf{7}$ & Very Poor & 7 & 23,33 & 0 & 0 \\
\hline
\end{tabular}
Total
$30 \quad 100 \%$
$30 \quad 100 \%$

Based on the table above, it can be seen that in the pre-test consisted of 30 students; most of them were in good to average category. $2(6.67 \%)$ students got fairly good, 21 (70.00\%) students got poor, and 7 (23.33\%) students got very poor.

In the post-test, the number of students who got very good had improved to $(13.33 \%)$ or 4 students. Meanwhile, the number of students who got good (40\%) or 12 students, the number of students got fairly good $(33.33 \%)$ or 10 students and number of students got fair $(13.33 \%)$ or 4 students, and not students gets poor and very poor.

\subsection{Mean score and Standard Deviation}

After classifying the vocabulary achievement, the next are the mean score and the standard deviation in the pre-test and post-test which can be shown in the following table:

Table 2. Mean Score Standard Deviation of the Students in Pre-test and Post-test

\begin{tabular}{lcc}
\hline & Pre-test & Post-test \\
\hline Mean score & 41,77 & 75,44 \\
\hline $\begin{array}{l}\text { Standard } \\
\text { Deviation }\end{array}$ & 11,02 & 8,5 \\
\hline
\end{tabular}

\subsection{Significant Test}

In other to know whether or not the mean score was different from the two test (pre-test and post-test), the researcher used the T-table. The following table shows the result of the T-test calculating below:

Table 3. The t-test of students' achievement

\begin{tabular}{ccc}
\hline Variable & T-test & T-table \\
\hline $\mathrm{X} 2-\mathrm{X} 1$ & 16,28 & 2,045 \\
\hline
\end{tabular}

The table above shows that the level of significance (p) 0.05 and df 16, the value of the t-test (16.28) is higher than t-table 2.045. It means that there is significant difference between the result of the students' pre-test and post-test achievement after giving the treatment by using gesture.

\subsection{Test the Hypothesis}

To find out the degree of freedom $(d f)$, the researcher used the following formula:

$$
\begin{aligned}
d f & =\mathrm{N}-1(\mathrm{~N}=\text { Number of students }) \\
d f & =30-1 \\
d f & =29
\end{aligned}
$$


For the level of significance (p) 0.05 and df 29, the value of the t-test $(16,28)$ was higher than t-table $(2.045)$. It means that $\mathrm{HO}$ is rejected and $\mathrm{H} 1$ is accepted. So, the researcher concludes that there is significant difference between the result of the students' pre-test and pos-test achievement after using gesture.

\subsection{Students' Interest}

The questionnaire was used to measure the students' interested in vocabulary by gesture. The questionnaire consisted of some questions that related to students interested to the strategy which had 5 choices: strongly agree, agree, neutral, disagree, and strongly disagree. The questionnaire is given after the post-test given.

The percentage in the questionnaire could be seen on the table below:

Table 4. The percentage of students' interest

\begin{tabular}{ccccc}
\hline No & $\begin{array}{c}\text { Interval } \\
\text { Score }\end{array}$ & Category & Frequency & Percentage \\
\hline 1 & $81-100$ & $\begin{array}{c}\text { Very } \\
\text { high }\end{array}$ & 25 & $83,33 \%$ \\
\hline 2 & $61-80$ & High & 5 & $16,67 \%$ \\
\hline 3 & $41-60$ & Moderate & 0 & 0 \\
\hline
\end{tabular}

\begin{tabular}{ccccc}
\hline 4 & $21-40$ & Low & 0 & 0 \\
\hline 5 & $0-20$ & Very low & 0 & 0 \\
\hline \multicolumn{2}{l}{ Total } & & 30 & $100 \%$ \\
\hline
\end{tabular}

$$
\begin{array}{cc}
P=\frac{F}{N} \times 100 & P=\frac{F}{N} \times 100 \\
P=\frac{25}{30} \times 100 & P=\frac{5}{30} \times 100 \\
P=83.33 \% & P=16.67 \%
\end{array}
$$

In this section, the discussion deals with the interpretation of the findings derived from the result of statistical analysis through vocabulary test by using Gesture both pre-test and post-test.

The description of the data that collected in the pretest and post-test as explained that the students' achievement in vocabulary improved significantly. It was supported by the mean score rate of students' pretest and posttest of the experimental group. The mean score of the students' pretest and posttest of experimental group were 41.77 and 75.44. The data in the previous section also showed that the used of gesture in teaching vocabulary was more effective in improving students' vocabulary achievement.
The mean score gesture improved after they were given treatments. The improvement of students' vocabulary was marked by the result of the post-test. In pre-test, there were students got fairly good 2, poor 21 , very poor 7 and there is not student got excellent, very good, good, and poor. After giving treatment at the experimental group, the result there were students that got very good (4), good (12) fairly good (10), and fair (4).

The data indicated that using gesture in teaching vocabulary were influenced the students' vocabulary achievement. Based on the data analysis and discussion, the researcher can assume that gesture can improved the students' vocabulary after the treatment was conducted. It can be seen in the result of the students' mean score and standard deviation after treatment of posttest.

The mean score of the students' score improved after they were given treatments. The students were taught vocabulary by using gesture. After analyzing questionnaire, the researcher found that the data above indicated that the students were very high interested in studying vocabulary by using gesture.

\section{Conclusion and Suggestion}

Based on the result of the research, the researcher concludes that using gesture in teaching English vocabulary improve the students' vocabulary achievement. It was proved by the data of students score in pre-test and post-test before and after doing gesture activity. The table of both scores showed that students' mean score in the post-test (75.44) was higher than the mean score of the students in pre-test (41.77). The students' vocabulary mastery improved after doing some treatments by using gesture. So, it concluded that the used of gesture was effective to improved students' vocabulary achievement to the second grade students of Indonesian junior high school. Gesture activity was very high interesting to the second grade students of Indonesian junior high school. It showed by the table that most of students got high score at the mean score in questionnaire was 8064.52 which stayed on very high interesting.

In view of fact that the used gesture in teaching English vocabulary achievement, has been proved being more effective in improving the students' vocabulary achievement and the students' interested in learning English vocabulary. Yet, the researcher would like to give suggestions that the English teacher should be more creative to manage the material and the classroom for teaching English vocabulary such as using gesture, the English teacher should apply gesture as one of the effective ways to stimulate the students' ability in extending their vocabulary achievement, the teacher should pay much attention to the students' weaknesses in studying English in order the students felt to be 
motivated. Therefore, this motivation will indirectly their interests in studying English vocabulary. If they are interested in the subject, they will have more concentration and gain successful.

\section{References}

Andrén, M. (2010). Children's gestures between 18 and 30 months. Lund: Media Tryck.

Apdy, A. P. R., \& Asrifan, A. (2019, April). The Chinese mime game in teaching vocabulary on EFL classroom. In Proceedings of the 65th TEFLIN International Conference (Vol. 65, No. 01).

Aswad, M., Rahman, F., Said, I. M., Hamuddin, B., \& Nurchalis, N. F. (2019). A Software to Increase English Learning Outcomes: An Acceleration Model of English as the Second Language. The Asian EFL Journal. 26.(6.2), 157, 169.

Asyiah, D. N. (2017). The Vocabulary Teaching and Vocabulary Learning: Perception, Strategies, and Influences on Students' Vocabulary Mastery. Jurnal Bahasa Lingua Scientia, 9(2), 293-318.

Beattie, G. (2016). Rethinking body language: How hand movements reveal hidden thoughts. Psychology Press.

Djufry, M. (2010). Motivating the Second Year Students of MA Madani Pao-Pao Gowa in Memorizing English Vocabulary by Using Mind Map (Fishbone Model) Strategy (Doctoral dissertation, Universitas Islam Negeri Alauddin Makassar).

Gower, R., Walters, S., \& Phillips, D. (1983). Teaching practice handbook. London: Heinemann.

Gusman, G. (2018). The Effectiveness of Gesture toward the Vocabulary Mastery of the Second Year Students of Junior High School at SMPN 18 Makassar (Doctoral dissertation, Universitas Islam Negeri Alauddin Makassar).

Harmer, J. (1991). The Practical of English Language Teaching. Third Edit.

Hornby, A. S., \& Cowie, A. P. (1995). Oxford advanced learner's dictionary (Vol. 1430). Oxford: Oxford university press.

Kusumayati, L. D. (2010). Improving students' vocabulary mastery using contextual teaching and learning (a classroom action research at the third grade of SD Negeri Kalimacan in academic year 2009/2010).

Muhammad, S. S. (2014). The Relation Between Using Facebook As Media Comunication and Students' Interest Toward English Language. Watampone: STAIN Watampone.
Octavita, A. I. (2019). Developing Students' Writing Skill By Using Picture Media. Jurnal Inovasi Pendidikan MH Thamrin, 3(2), 12-17.

Shangavi, S., Jeyamaalmarukan, S., Jathevan, A., Umatharsini, M., \& Samarasinghe, P. (2018, October). Self-Speech Evaluation with Speech Recognition and Gesture Analysis. In 2018 National Information Technology Conference (NITC) (pp. 1-7). IEEE.

Sugiyono, S. (2009). Metode Penelitian Kuantitatif, Kualitatif dan R\&D, Cetakan 8. Alfabeta, Bandung.

Sukmadinata, N. S. (2005). Metode penelitian pendidikan. Program Pascasarjana Universitas Pendidikan Indonesia dengan PT Remaja Rosdakarya.

Wirawan, R. (2014). increasing Vocabulary mastery of the seventh grade students through snowball throwing. e-Journal of ELTS (English Language Teaching Society), 1(2), 1-15

Wishon, G. E \& Burks. Julia M. 1980. Let's write English. Newyork: Litton E. Publishing, 